\author{
Marcin Salamaga \\ Katedra Statystyki \\ Uniwersytet Ekonomiczny w Krakowie
}

\title{
Zastosowanie modelu VECM do badania długookresowej zależności pomiędzy eksportem i wzorcem przewag komparatywnych w Polsce
}

\section{Streszczenie}

W artykule badano dynamiczne zależności pomiędzy eksportem i polskim wzorcem przewag komparatywnych. Podstawowym narzędziem zastosowanym do przeprowadzenia tego badania są wektorowe modele autoregresji. W celu bardziej szczegółowej identyfikacji dynamiki oddziaływań zwrotnych pomiędzy zmiennymi przeanalizowano również wyniki funkcji odpowiedzi na impuls i dekompozycji wariancji prognoz. Całokształt wyników stanowi podstawę do określenia fazy rozwoju gospodarczego według teorii dynamicznych przewag komparatywnych T. Ozawy, której ważnym ogniwem jest długookresowa relacja eksportu i wskaźników przewag komparatywnych towarów o różnym stopniu nasycenia czynnikami produkcji. W obliczeniach posłużono się danymi z Głównego Urzędu Statystycznego obejmującymi okres od pierwszego kwartału 2002 r. do czwartego kwartału 2012 r.

Słowa kluczowe: eksport, wskaźnik ujawnionej przewagi komparatywnej, model VAR, model VECM. 


\section{Wprowadzenie}

Konkurencyjność gospodarki narodowej jest zagadnieniem wieloaspektowym. Może być ona rozpatrywana w kategorii innowacyjności, atrakcyjności dla mobilnych czynników wytwórczych lub konkurencyjności eksportu. Ta ostatnia kategoria jest wypadkową wielu czynników, takich jak: struktura produkcji, jakość towarów i usług, poziom kosztów pracy czy cen krajowych względem zagranicznych, co znajduje odzwierciedlenie w występowaniu przewag komparatywnych grup towarowych, branż gospodarki itd. Przewagi komparatywne już według klasycznych teorii ekonomii międzynarodowej warunkowały wzrost obrotów w handlu zagranicznym oraz dawały szansę na poprawę salda bilansu handlowego [Krugman i Obstfeld 2007]. Dość precyzyjnego wyjaśnienia mechanizmu powiązań branżowych przewag komparatywnych z eksportem i bezpośrednimi inwestycjami zagranicznymi (BIZ) we współczesnych gospodarkach dostarcza teoria dynamicznych przewag komparatywnych [Ozawa 1992]. T. Ozawa opracował teoretyczny model rozwoju gospodarczego, zgodnie z którym systematyczny napływ bezpośrednich inwestycji zagranicznych kolejno do branż surowcochłonnych, pracochłonnych, kapitałochłonnych i technologicznie intensywnych wzmacniania konkurencyjność towarów w nich wytwarzanych, co przekłada się na stopniowy wzrost eksportu i docelowo na dobrobyt w całej gospodarce. Ewolucyjne zmiany w strukturze gospodarki możliwe dzięki napływowi BIZ do branż coraz bardziej zaawansowanych technologicznie mają w założeniu twórcy modelu przekładać się docelowo na wzrost poziomu rozwoju gospodarczego. Aktualne stadium rozwoju w przedmiotowej teorii ekonomii można ustalić na podstawie rosnącej konkurencyjności międzynarodowej określonej branży generującej wzrost eksportu. W związku z tym badanie dynamicznych zależności pomiędzy aktualnym wzorcem przewag komparatywnych (wynikającym z wartości wskaźników tych przewag w głównych grupach towarowych czy branżach produkcyjnych) i poziomem eksportu wydaje się główną kwestią w identyfikacji stadium rozwoju gospodarczego kraju w sensie teorii T. Ozawy.

Długookresowe zależności pomiędzy wzorcem przewag komparatywnych i eksportem w literaturze są przeważnie przedmiotem rozważań teoretycznych rzadko popartych rzeczową analizą empiryczną zwłaszcza przy wykorzystaniu narzędzi ekonometrycznych (por. [Ozawa 1992, Damijan i Rojec 2004, Cutler i Ozawa 2007, Tarasiński 2009, Koyama 2011, Salamaga 2013]).

W szczególności w dotychczasowych analizach omawianej problematyki brakuje implementacji zaawansowanych modeli szeregów czasowych stanowiących dorobek współczesnej ekonometrii, które wydają się optymalnym narzędziem w opisaniu dynamicznych zależności pomiędzy eksportem i wskaźnikiem ujawnionej przewagi komparatywnej (Revealed Comparative Advantage Index 
$-R C A$ ). Niniejszy artykuł stanowi próbę wypełnienia tej luki. Autor stawia sobie za cel zbadanie dynamicznych zależności pomiędzy eksportem i wskaźnikiem $R C A$ dóbr o różnym nasyceniu czynnikami produkcji. Cel badawczy zostanie zrealizowany za pomocą wektorowych modeli autoregresji. Dodatkowo stronę empiryczną badań wzbogacono, stosując funkcję odpowiedzi na impuls i dekompozycję wariancji prognoz poszczególnych zmiennych. Całokształt wyników będzie stanowić podstawę do identyfikacji fazy rozwoju gospodarczego według teorii dynamicznych przewag komparatywnych T. Ozawy.

\section{Metoda badawcza}

Wzorzec przewag komparatywnych w niniejszych badaniach tworzono na podstawie wartości wskaźników $R C A$, które obliczono osobno dla dóbr: surowcochłonnych (RCAs), pracochłonnych (RCAp), kapitałochłonnych (RCAk) i technologicznie intensywnych $(R C A t)$. W tym celu skorzystano ze wzoru [Misala 2011]:

$$
R C A_{i}=\ln \left(E x_{i} \cdot \operatorname{Im}\right)-\ln \left(E x \cdot \operatorname{Im}_{i}\right),
$$

gdzie:

$E x_{i}-$ wartość eksportu $i$-tej grupy towarowej,

$I_{i}$ - wartość importu $i$-tej grupy towarowej,

Ex - całkowita wartość krajowego eksportu,

Im - całkowita wartość krajowego importu.

Im wyższą wartość przyjmuje miernik (1) w $i$-tej grupie towarowej, tym wyższą przewagą komparatywną cechują się towary w tej grupie. Przyporządkowanie towarów do poszczególnych grup przeprowadzono na dwucyfrowym poziomie dezagregacji, stosując Międzynarodową Standardową Klasyfikację Handlu (Standard International Trade Classiffication - SITC) [Misala i Pluciński 2000].

W obliczeniach posłużono się danymi z Głównego Urzędu Statystycznego obejmującymi okres od pierwszego kwartału 2002 r. do czwartego kwartału $2012 \mathrm{r}^{1}$. W badaniu dynamicznych relacji pomiędzy eksportem i wskaźnikami przewagi komparatywnej posłużono się modelem wektorowej autoregresji (Vector Autoregression model - model VAR) i modelem wektorowej korekty błędem (Vector Error Correction Model - model VECM). Model VAR można przedstawić następująco [Lütkepohl 2007, Osińska, Kośko i Stempińska 2007]:

${ }^{1}$ http://www.stat.gov.pl/gus/wskazniki_makroekon_PLK_HTML.htm (dostęp: 10.03.2014). Ograniczenie się do okresu I. kw. 2002-IV. kw. 2012 było uwarunkowane dostępnością kompletnych danych kwartalnych. 


$$
\boldsymbol{X}_{\boldsymbol{t}}=\boldsymbol{A}_{\mathbf{0}} \boldsymbol{D}_{\boldsymbol{t}}+\sum_{i=1}^{k} \boldsymbol{A}_{i} \boldsymbol{X}_{t-i}+\boldsymbol{\varepsilon}_{t}
$$

gdzie:

$\boldsymbol{X}_{\boldsymbol{t}}$ - wektor obserwacji bieżących wartości analizowanych procesów,

$\boldsymbol{D}_{\boldsymbol{t}}-$ wektor zawierający składniki deterministyczne (np. trend, sezonowość),

$\boldsymbol{A}_{\boldsymbol{i}}-$ macierz autoregresyjnych operatorów poszczególnych procesów,

$\boldsymbol{A}_{\mathbf{0}}$ - macierz parametrów przy składnikach wektora $\boldsymbol{D}_{\boldsymbol{t}}$,

$\boldsymbol{\varepsilon}_{t}-$ wektor procesów resztowych,

$k$-rząd modelu VAR.

W modelu VAR odchodzi się od klasycznego rozróżnienia pomiędzy zmiennymi endogenicznymi i egzogenicznymi, a także nie stosuje się w nim ograniczeń co do wartości parametrów [Osińska 2006]. W warunkach kointegracji szeregów czasowych stosowany jest przeważnie model VECM. Skointegrowanie szeregów czasowych oznacza istnienie wspólnej długookresowej ścieżki równowagi dla tych szeregów. W praktyce kointegracja występuje, gdy szeregi czasowe nie są stacjonarne $^{2}$ (najczęściej są zintegrowane w stopniu pierwszym) oraz istnieje ich stacjonarna kombinacja liniowa. W badaniach zjawiska kointegracji stosuje się najczęściej test śladu, test maksymalnej wartości własnej [Johansen 1991, 1992] lub procedurę Engle'a-Grangera. Model VECM można zapisać następująco (por. [Johansen 1995, Kusideł 2000]):

$$
\Delta \boldsymbol{X}_{\boldsymbol{t}}=\boldsymbol{\Psi}_{\mathbf{0}} \boldsymbol{D}_{\boldsymbol{t}}+\sum_{i=1}^{k-1} \Pi_{i} \Delta \boldsymbol{X}_{t-i}+\Pi \boldsymbol{X}_{t-1}+\xi_{t}
$$

gdzie:

П - macierz współczynników zawierająca efekty krótkookresowych dostosowań oraz długookresowe zależności kointegrujące, $\Pi=\sum_{i=1}^{k} \boldsymbol{A}_{i}-\boldsymbol{I}$,

$\Psi_{\mathbf{0}}-$ macierz współczynników przy składnikach deterministycznych wektora $D_{t}$, $\boldsymbol{\Pi}_{i}-$ macierz współczynników autoregresji, $\boldsymbol{\Pi}_{i}=-\sum_{i=j+1}^{k} \boldsymbol{A}_{i}$,

$\xi_{t}-$ proces białoszumowy.

Złożoność struktury przedmiotowego modelu, wzajemne interakcje zmiennych mogą utrudniać interpretację parametrów. W związku z tym, aby w selektywny sposób przeanalizować wpływ pojedynczej zmiennej na inną zmienną,

${ }^{2}$ Szereg czasowy nazywany jest stacjonarnym, jeżeli po obliczeniu różnic rzędu $d$ jest on sprowadzony do stacjonarności. Stacjonarność szeregu bada się za pomocą odpowiednich testów, np. testu Dickeya-Fullera czy KPSS (por. [Charemza i Deadman 1997, Osińska, Kośko i Stempińska 2007]). 
stosuje się funkcję odpowiedzi na impuls. W tym celu model wektorowej autoregresji sprowadzany jest do procesu średniej kroczącej, w którym uwzględnia się również oddziaływania zakłóceń losowych [Osińska, Kośko i Stempińska 2007]:

$$
\boldsymbol{X}_{t}=\sum_{i=1}^{\infty} \boldsymbol{\Phi}_{i} \xi_{t-i}
$$

gdzie: $\Phi_{i}=\boldsymbol{A}_{1}^{i} \boldsymbol{B}^{-1}, \boldsymbol{B}$ - macierz parametrów stojących przy nieopóźnionych wartościach składowych wektora $\boldsymbol{X}_{\boldsymbol{t}}$.

Elementy macierzy $\boldsymbol{\Phi}_{i}$ można interpretować jako odpowiedzi dowolnej zmiennej wektora $\boldsymbol{X}_{\boldsymbol{t}}$ na impuls ze strony innej zmiennej tego wektora przy założeniu warunków ceteris paribus. Metodą uzupełniającą analizę interakcji pomiędzy zmiennymi jest dekompozycja wariancji błędów prognoz poszczególnych składowych wektora $\boldsymbol{X}_{\boldsymbol{t}}$. Umożliwia ona ustalenie udziału każdej składowej tego wektora $\mathrm{w}$ wyjaśnieniu błędu prognozy wyróżnionej zmiennej prognozowanej [Kusideł 2000, Papież i Śmiech 2012].

\section{Wyniki estymacji modelu}

Wybór pomiędzy modelami VAR i VECM poprzedzono badaniem stacjonarności szeregów czasowych, ustaleniem optymalnego rzędu opóźnienia zmiennych i badaniem kointegracji szeregów czasowych. Posługując się rozszerzonym testem Dickeya-Fullera (test ADF) [Charemza i Deadman 1997], stwierdzono, że żaden z szeregów czasowych utworzonych z wartości zmiennych $R C A s$, $R C A p, R C A k, R C A t$, eksport (Ex) nie jest stacjonarny na poziomie istotności 0,05 , natomiast pierwsze przyrosty tych zmiennych są stacjonarne. Wskazuje to na pierwszy stopień integracji szeregów czasowych. Wyboru optymalnego rzędu opóźnienia zmiennych w modelu dokonano, posługując się kryteriami informacyjnymi Akaike (AIC) i Schwarza (BIC). Wyniki dla tych kryteriów przedstawiono w tabeli 1.

Tabela 1. Wyniki kryteriów wyboru optymalnego opóźnienia zmiennych

\begin{tabular}{|c|c|c|}
\hline Rząd opóźnienia & AIC & BIC \\
\hline 1 & 6,1087 & 8,1566 \\
\hline 2 & 5,0711 & 8,1429 \\
\hline 3 & 4,8996 & 8,9954 \\
\hline 4 & 4,5716 & 9,6913 \\
\hline
\end{tabular}

Źródło: obliczenia własne. 
Kryterium informacyjne AIC osiąga najmniejszą wartość przy opóźnieniu rzędu czwartego, a kryterium BIC - przy opóźnieniu zmiennych rzędu drugiego. $Z$ uwagi na ryzyko uzyskania statystycznie nieistotnych parametrów modelu przy zbyt dużym rzędzie opóźnienia (parametry przy dalszych opóźnieniach) [Papież i Śmiech 2012] zdecydowano się ostatecznie na wybór opóźnienia rzędu drugiego zgodnie z wynikiem kryterium BIC.

Badanie kointegracji szeregów czasowych przeprowadzono za pomocą testu śladu i testu maksymalnej wartości własnej [Johansen 1991, 1992]. W tabeli 2 zamieszczono wyniki obu testów (w nawiasach znajdują się prawdopodobieństwa testowe). Przedstawione rezultaty wskazują na poziomie istotności 0,05 na występowanie kointegracji rzędu pierwszego.

Tabela 2. Wyniki testu kointegracji

\begin{tabular}{|c|c|c|c|}
\hline $\begin{array}{c}\text { Hipotezy statystyczne dotyczące } \\
\text { liczby wektorów kointegrujących }(r)\end{array}$ & Wartość własna & Test śladu & Test Lmax \\
\hline $\mathrm{H}_{0}: r=0 ;$ & 0,7076 & $\begin{array}{c}109,3300 \\
(0,0000)\end{array}$ & $\begin{array}{c}56,5610 \\
(0,0000)\end{array}$ \\
\hline $\mathrm{H}_{1}: r>0$ & 0,5543 & $\begin{array}{c}52,7660 \\
(0,0899)\end{array}$ & $\begin{array}{c}37,1760 \\
(0,0510)\end{array}$ \\
\hline $\mathrm{H}_{0}: r=1 ;$ & 0,1981 & $\begin{array}{c}15,5900 \\
(0,9188)\end{array}$ & $\begin{array}{c}10,1550 \\
(0,8897)\end{array}$ \\
\hline $\mathrm{H}_{1}: r>1$ & 0,1111 & 5,4356 & 5,4187 \\
$\mathrm{H}_{0}: r=2 ;$ & $0,9038)$ & $(0,8638)$ \\
\hline $\mathrm{H}_{1}: r>2$ & 0,0004 & $\begin{array}{c}0,0169 \\
(0,8966)\end{array}$ & $\begin{array}{c}0,0169 \\
(0,8966)\end{array}$ \\
\hline $\mathrm{H}_{1}: r=3 ;$ & & & \\
\hline $\mathrm{H}_{0}: r=4 ;$ & & & \\
\hline $\mathrm{H}_{1}: r>4$ & & & \\
\hline
\end{tabular}

Źródło: obliczenia własne.

W związku z potwierdzeniem kointegracji szeregów czasowych w badaniu dynamicznych zależności pomiędzy wzorcem przewag komparatywnych i eksportem zastosowano model VECM. Ze wstępnej analizy dynamicznej struktury szeregów czasowych wynika konieczność wprowadzenia do przedmiotowego modelu deterministycznego trendu liniowego (zmienna czasowa $t$ ) i efektów sezonowych $\left(S_{i}\right)$, tj. $\boldsymbol{D}_{\boldsymbol{t}}=\left[S_{1}, S_{2}, S_{3}, t\right.$, const $]$ i $\boldsymbol{X}_{\boldsymbol{t}}=[E x, R C A s, R C A p, R A C k, R A C t]$. Wyniki ocen parametrów modelu przedstawiono w tabeli 3. Ostatni wiersz tej tabeli zawiera oceny składnika korekty błędem EC1 reprezentującego mechanizm krótkookresowych dostosowań służący dochodzeniu do długookresowego stanu równowagi modelowanej zmiennej. W kolejnych równaniach dla zmiennych $\Delta E x$, $\triangle R C A s, \triangle R C A p, \triangle R C A k$ i $\triangle R C A t$ otrzymano współczynniki determinacji równe odpowiednio $97,4 \%, 66,4 \%, 67,0 \%, 68,2 \%$ i 59,5\%, które wskazują na umiarkowanie dobre dopasowanie równań do danych empirycznych. 


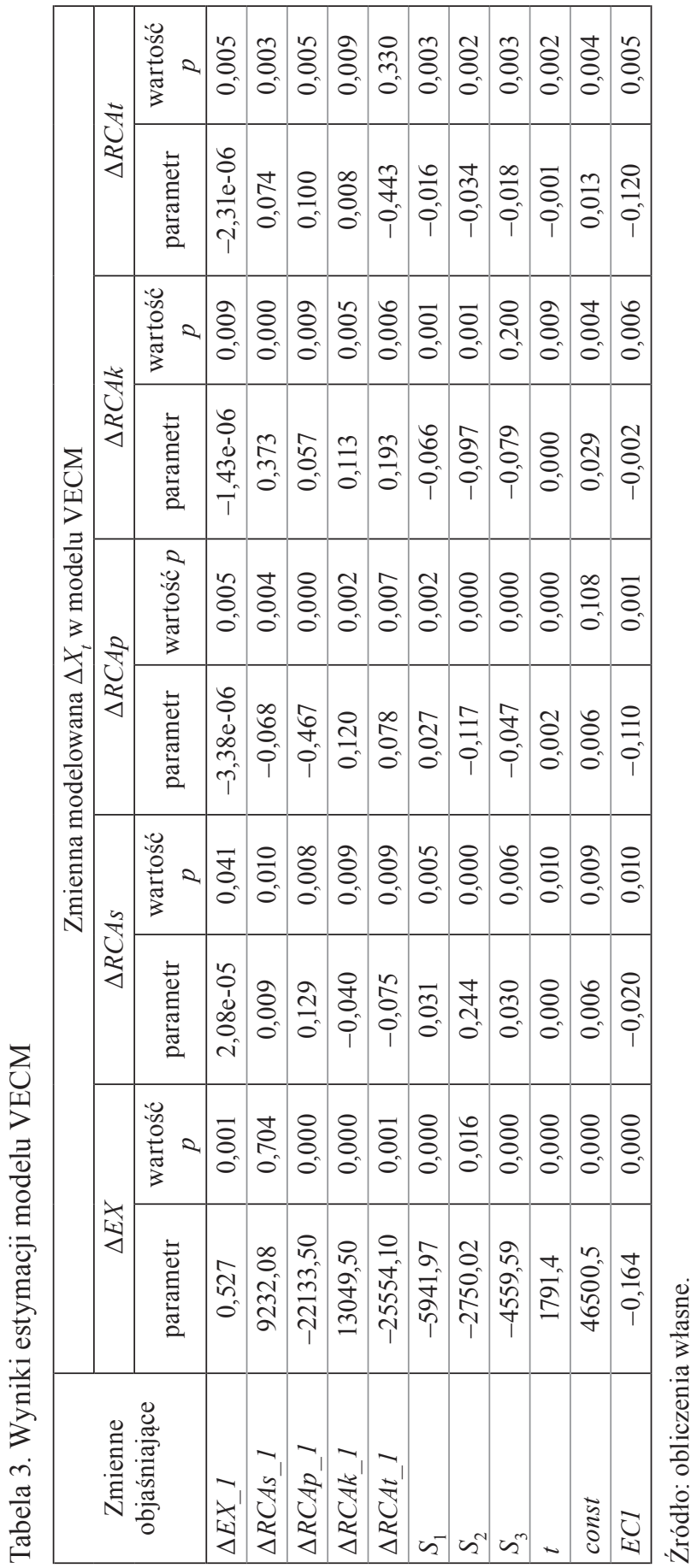


Na podstawie danych w tabeli 3 można stwierdzić, że na eksport statystycznie istotnie oddziałują wszystkie zmienne $\mathrm{z}$ wyjątkiem przewag komparatywnych dóbr surowcochłonnych. Wzrost zmiany eksportu w okresie bieżącym można osiągnąć poprzez wzrost eksportu, przewag komparatywnych dóbr surowcochłonnych, kapitałochłonnych w okresie poprzednim, jak i w wyniku upływu czasu w warunkach ceteris paribus. Wzrost pozostałych zmiennych w warunkach ceteris paribus powoduje przeciętnie obniżenie $\Delta E x$. Najsilniej $\Delta E x$ reaguje na $\triangle R C A t_{-} 1$ : wzrost przewagi komparatywnej dóbr technologicznie intensywnych w okresie poprzednim o 0,01 woduje spadek zmiany eksportu w okresie bieżącym przeciętnie o około 255,5 mln EUR przy założeniu, że pozostałe zmienne nie ulegną zmianie. Ujemne znaki ocen parametrów stojących przy zmiennych $\triangle R C A p_{-} l$ oraz $\Delta R C A t_{-} l \mathrm{w}$ modelu przyrostów eksportu mogą wskazywać słabszą konkurencyjność eksportu w zakresie towarów pracochłonnych i technologicznie intensywnych przy założeniu krótkookresowej relacji pomiędzy przedmiotowymi zmiennymi. Warto też przypomnieć, że w teorii T. Ozawy zakłada się ewolucyjny charakter wzorca przewag komparatywnych: przewagi komparatywne dóbr o niższym stopniu nasycenia czynnikami produkcji z czasem tracą znaczenie na rzecz przewag o wyższym stopniu nasycenia czynnikami produkcji. Niższy poziom eksportu wywołany zmniejszonym poziomem przewag komparatywnych w jednych branżach jest w ujęciu T. Ozawy kompensowany wzrostem eksportu wynikającym z poprawy przewag komparatywnych w innych branżach.

Z kolei wzrost zmiany eksportu w okresie poprzednim implikuje w okresie bieżącym istotny wzrost: zmiany eksportu, przewag komparatywnych dóbr surowcochłonnych oraz spadek zmiany przewag komparatywnych dóbr pracochłonnych, kapitałochłonnych i technologicznie intensywnych w warunkach ceteris paribus. Przykładowo wzrost $\triangle E x$ o 1 mld EUR w okresie poprzednim spowoduje w okresie bieżącym, przy założeniu warunków ceteris paribus, wzrost $\triangle R C A s$ przeciętnie o 0,0208 , spadek $\triangle R C A p$ przeciętnie o 0,00338 , spadek $\triangle R C A k$ przeciętnie o 0,00143 i spadek $\triangle R C A t$ przeciętnie o 0,00231 . Oceny parametrów składnika korekty błędem $E C 1$ są ujemne we wszystkich równaniach modelu VECM, co zapewnia dochodzenie do stanu równowagi poprzez krótkookresowy proces dostosowań w przypadku wszystkich zmiennych. Najsilniejsza korekta odchylenia od długookresowej równowagi występuje w przypadku pierwszego równania, w którym modelowana jest zmienna $\Delta E X$. Tutaj około $16,4 \%$ nierównowagi od długookresowej ścieżki wzrostu jest korygowane przez krótkookresowy proces dostosowań. 


\section{Analiza wyników funkcji odpowiedzi na impuls i dekompozycji wariancji prognoz}

W celu wyczerpującego przeanalizowania sprzężeń zwrotnych pomiędzy eksportem i wskaźnikami ujawnionej przewagi komparatywnej dóbr o różnym stopniu nasycenia czynnikami produkcji przeprowadzono analizę przebiegu funkcji odpowiedzi na impuls. Na rys. 1 zilustrowano przebieg funkcji odpowiedzi eksportu na impuls ze strony wskaźników przewag komparatywnych $R C A s, R C A p, R C A k$ i $R C A t$. Wnika z niego, że reakcja eksportu na szokową zmianę ze strony przedmiotowych wskaźników ma na początku charakter cykliczny, a następnie stabilizuje się zwykle po 3-4 latach. W pierwszym kwartale w eksporcie odnotowano wzrost na skutek impulsu ze strony przewag komparatywnych dóbr kapitałochłonnych i technologicznie intensywnych oraz spadek w wyniku impulsu ze strony przewag komparatywnych dóbr surowcochłonnych i pracochłonnych, a w kolejnych kwartałach występowały naprzemiennie spadki lub wzrosty wartości eksportu, przy czym amplitudy zmian mają charakter gasnący. Warto zauważyć, że największy zakres zmian eksportu powoduje impuls ze strony wskaźnika ujawnionej przewagi komparatywnej dóbr surowcowych oraz ze strony wskaźnika ujawnionej przewagi komparatywnej dóbr kapitałochłonnych. Jednorazowe szoki ze strony ujawnionych przewag komparatywnych oddziałują natychmiast, ale wygasają dopiero w perspektywie kilku lat. W rezultacie proces dostosowań eksportu do zmieniającego się wzorca przewag komparatywnych jest powolny. Najdłużej podtrzymywany jest impuls ze strony wskaźnika $R C A k$, a najkrócej ze strony wskaźnika $R C A s$. Trwałe podwyższenie poziomu eksportu na skutek efektu niedopasowań w długim okresie było wywołane impulsem ze strony przewag komparatywnych dóbr pracochłonnych i technologicznie intensywnych, natomiast trwałe obniżenie poziomu eksportu w długim okresie było efektem impulsu ze strony przewag komparatywnych dóbr surowcochłonnych i kapitałochłonnych.

Zwrotne oddziaływanie, tj. reakcję wskaźników przewag komparatywnych na impuls ze strony eksportu, zobrazowano za pomocą funkcji odpowiedzi na impuls na rys. 2. Na podstawie przebiegu przedstawionych krzywych można stwierdzić, że w pierwszych kwartałach po wystąpieniu impulsu wywołanego zwiększeniem wartości eksportu największy zakres zmian wykazał wskaźnik ujawnionej przewagi komparatywnej dóbr surowcochłonnych: po gwałtownym wzroście tego wskaźnika w pierwszym kwartale nastąpił silny spadek jego wartości w drugim i trzecim kwartale, kiedy to wskaźnik ten osiągnął najniższą wartość. Najsłabiej na szokową zmianę ze strony eksportu reagował z kolei wskaźnik przewagi komparatywnej dóbr technologicznie intensywnych, w przypadku którego zakres amplitudy wahań był najmniejszy. Przebieg krzywych na 


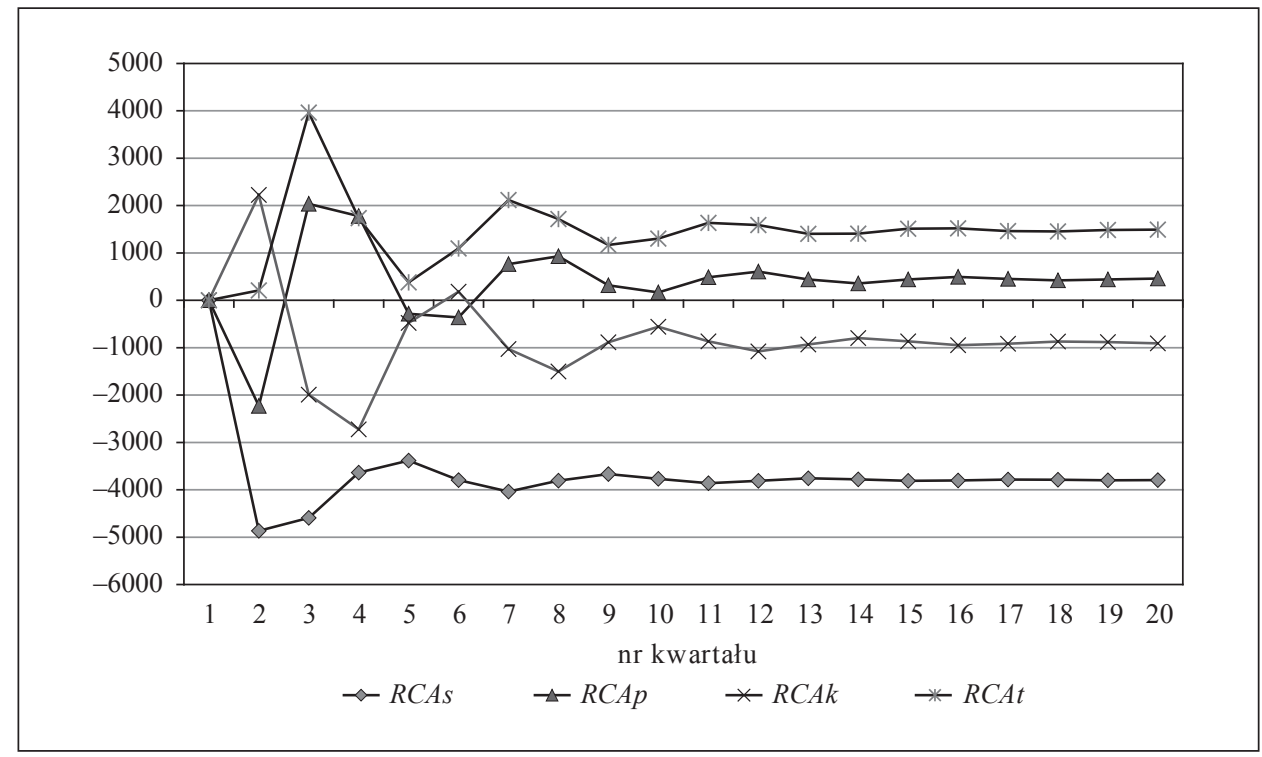

Rys. 1. Reakcja eksportu na impuls ze strony wskaźników przewagi komparatywnej dóbr o różnym stopniu nasycenia czynnikami produkcji

Źródło: opracowanie własne.

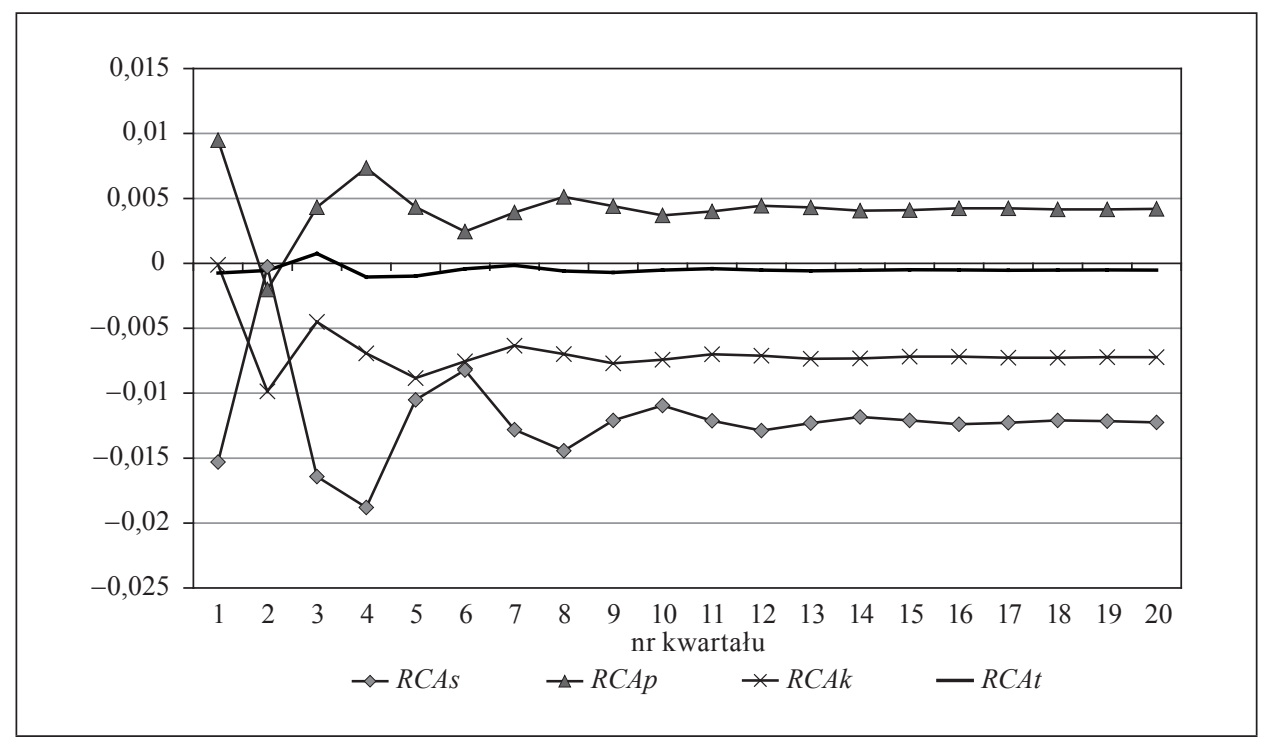

Rys. 2. Reakcja wskaźników przewag komparatywnych dóbr o różnym stopniu nasycenia czynnikami produkcji na impuls ze strony eksportu Źródło: opracowanie własne. 
rys. 2 pozwala również stwierdzić, że skutki szokowej zmiany eksportu najdłużej trwają w przypadku wskaźnika przewagi komparatywnej dóbr surowcochłonnych, a najszybciej wygasają w przypadku wskaźnika przewagi komparatywnej dóbr technologicznie intensywnych. Długookresowym efektem impulsu ze strony eksportu jest trwałe zwiększenie wartości wskaźnika $R C A p$ oraz trwałe obniżenie wartości pozostałych wskaźników $R C A$.

Aby zbadać wkład poszczególnych zmiennych w wyjaśnienie wariancji błędu prognoz obliczanych za pomocą modelu VECM, przeprowadzono dekompozycję tych wariancji. Wyniki przedstawiono na rys. 3 i 4.

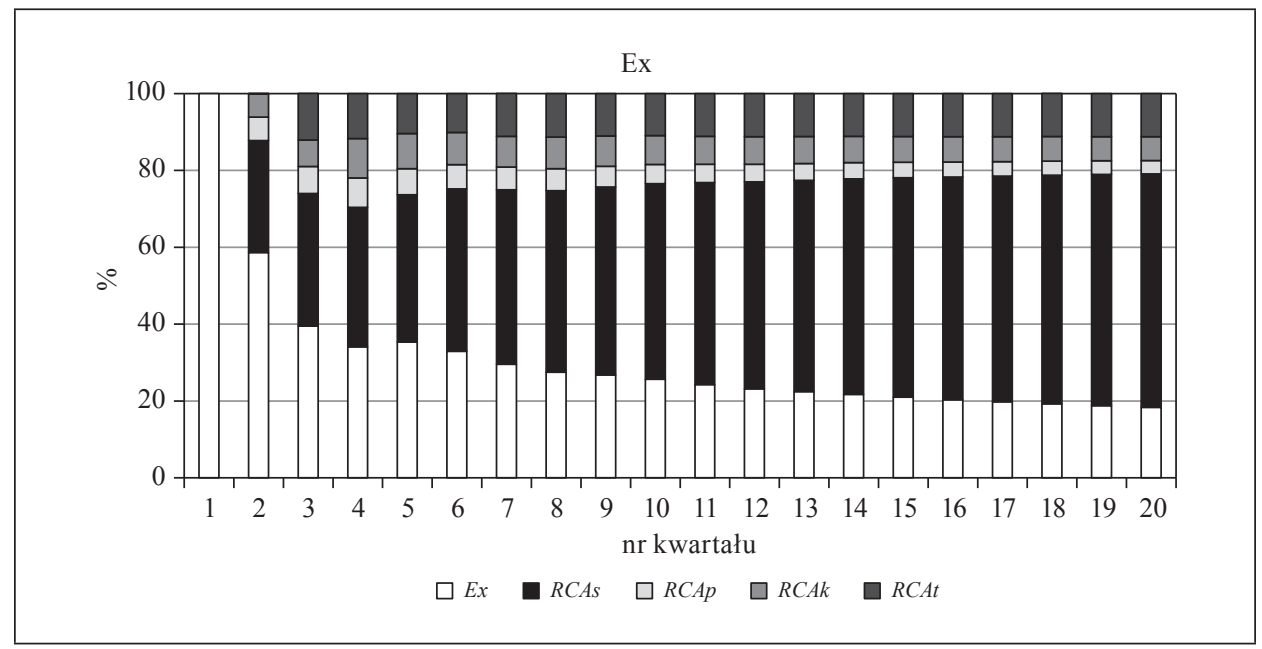

Rys. 3. Dekompozycja wariancji błędu prognoz eksportu

Źródło: opracowanie własne.

Z obu wykresów wynika, że najczęściej każda ze zmiennych wektora $\boldsymbol{X}_{\boldsymbol{t}}$ w najwyższym stopniu wyjaśnia wariancję błędu swoich prognoz, a udział pozostałych zmiennych w wariancji jest przeważnie najwyżej kilkunastoprocentowy. Najbardziej odbiega od tego schematu dekompozycja wariancji prognoz eksportu (rys. 3): udział samego eksportu w tej wariancji początkowo wynosił wprawdzie $100 \% \mathrm{w}$ pierwszym kwartale, ale w kolejnych okresach systematycznie malał do poziomu poniżej $20 \%$ po upływie czterech lat. Spadek udziału eksportu był tu kompensowany przede wszystkim systematycznym wzrostem udziału wskaźnika przewagi komparatywnej dóbr surowcochłonnych do poziomu powyżej $60 \%$ przy udziale pozostałych zmiennych na poziomie kilkuprocentowym. Analizując struktury wariancji prognoz wskaźników $R C A$, należy stwierdzić, że w dłuższym okresie są one w przybliżeniu stabilne, co ułatwia uporządkowanie zmiennych według stopnia egzogeniczności. „Najbardziej egzogeniczną” zatem zmienną 


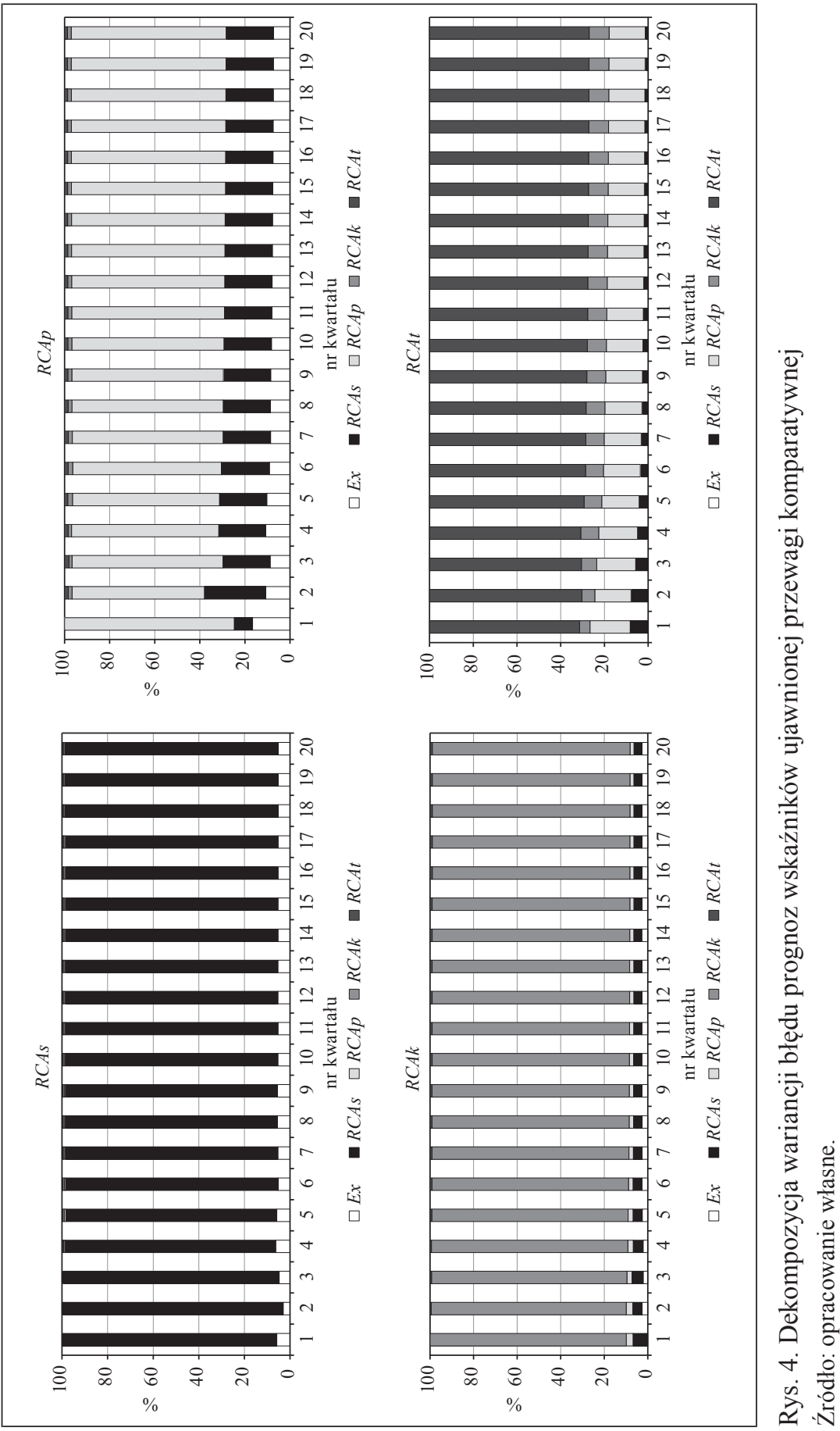


jest wskaźnik $R C A s$, drugą w kolejności $R C A k$, następnie $R C A t$, a najmniej „zaangażowaną" zmienną w wyjaśnienie własnej wariancji prognoz jest $R C A p$. W przypadku tej ostatniej zmiennej udział niepewności prognoz kształtuje się w dłuższym okresie na poziomie poniżej $70 \%$ przy udziale $R C A s$ wynoszącym około $20 \%$ i prawie dziesięcioprocentowym udziale eksportu. Z kolei wariancja prognoz wskaźnika ujawnionej przewagi komparatywnej dóbr technologicznie intensywnych jest w około $70 \%$ wyjaśniona przez zmienną $R C A t$, w około $16 \%$ przez $R C A p$ i w około $8 \%$ przez $R C A k$ (przy udziale pozostałych zmiennych na poziomie kilku procent).

Opisane zależności wskazują na wielokierunkowe oddziaływanie pomiędzy wzorcem przewag komparatywnych i eksportem. Zarówno zmiany impulsowe po stronie eksportu powodują zmiany we wzorcu przewag komparatywnych, jak i odwrotnie: zmiany szokowe wskaźników ujawnionej przewagi komparatywnej przenoszone są na poziom eksportu. Te sprzężenia zwrotne znajdują również implikacje w często znaczącym udziale niektórych regresorów w dekompozycji wariancji prognoz poszczególnych zmiennych.

\section{Podsumowanie}

Na podstawie przeprowadzonych badań można stwierdzić, że sposób impulsowego oddziaływania wzorca przewag komparatywnych na polski eksport (i odwrotnie) zależy od długości horyzontu czasowego. W krótszym okresie szokowe zmiany wskaźników przewag komparatywnych, przy założeniu warunków ceteris paribus, implikują cykliczne zmiany eksportu z gasnącą amplitudą w długim okresie. Za korzystny dla gospodarki można uznać fakt, że największy wzrost poziomu eksportu w długim okresie powoduje szokowa zmiana ze strony przewag komparatywnych dóbr technologicznie intensywnych, a największy spadek poziomu eksportu wywołuje impuls ze strony przewag komparatywnych dóbr surowcochłonnych. Kreacja eksportu na skutek wzrostu poziomu przewag komparatywnych dóbr technologicznie intensywnych i jednocześnie ograniczanie eksportu w wyniku wzrostu poziomu przewag dóbr surowcochłonnych są typowe dla gospodarek wysoko rozwiniętych (zgodnie z teorią T. Ozawy). Jednocześnie jednak eksport $\mathrm{w}$ długim okresie jest wzmacniany w wyniku impulsu ze strony przewag komparatywnych dóbr pracochłonnych i zmniejszany w efekcie szokowej zmiany ze strony przewag komparatywnych dóbr kapitałochłonnych. To z kolei zgodnie z modelem T. Ozawy może wskazywać, że eksportowa konkurencyjność polskiej gospodarki ma cechy gospodarek krajów średnio rozwiniętych. Oddziaływanie zwrotne, czyli długookresowe reakcje przewag komparatywnych na szokowy wzrost eksportu, także nie ułatwia 
jednoznacznej identyfikacji stadium rozwoju gospodarczego w rozumieniu teorii T. Ozawy. Analiza wyników dekompozycji wariancji wskazuje m.in., że w długim okresie niepewność prognoz eksportu będzie w znacznej mierze wyjaśniona zmiennością przewag komparatywnych dób surowcochłonnych, co również może wskazywać na cechy gospodarki we wczesnej fazie rozwoju. Należy stwierdzić, że otrzymane wyniki nie pozwalają w sposób jednoznaczny umiejscowić polskiej gospodarki w jednej fazie rozwoju, wskazują one bowiem na występowanie symptomów typowych zarówno dla bardziej zaawansowanych etapów rozwoju (charakterystycznych dla gospodarek zaawansowanych technologicznie), jak i typowych dla wczesnych etapów rozwoju (charakterystycznych dla gospodarek surowcochłonnych). Sygnalizowane tu etapy rozwoju gospodarczego są identyfikowane na podstawie modelu T. Ozawy, w którym relacje pomiędzy wzorcem przewag komparatywnych i eksportem stanowią ważne, ale nie jedyne ogniwo całego teorematu kreowania dobrobytu. Pełna weryfikacja zależności występujących w modelu T. Ozawy wymaga uwzględnienia jeszcze innych zmiennych, jak bezpośrednie inwestycje zagraniczne, czy PKB. Otwiera to możliwości kontynuacji badań nad weryfikacją przedmiotowego modelu w warunkach polskiej gospodarki.

\section{Literatura}

Charemza W.W., Deadman D.F. [1997], Nowa ekonometria, PWE, Warszawa.

Cutler H., Ozawa T. [2007], The Dynamics of the „Mature” Product Cycle and Market Recycling, Flying-Geese Style: An Empirical Examination and Policy Implications, „Contemporary Economic Policy”, vol. 25, nr 1, http://dx.doi.org/10.1111/j.14657287.2006.00018.x.

Damijan J. P., Rojec M. [2004], Foreign Direct Investment and the Catching-up Process in New EU Member States: Is There a Flying Geese Pattern?, Forschungsbericht, wiiw Research Reports 310, The Vienna Institute for International Economic Studies, Vienna.

Johansen S. [1995], Likelihood-Based Inference in Cointegrated Vector Autoregressive Models, Oxford University Press, Oxford.

Johansen S. [1991], Estimation and Hypothesis Testing of Cointegration Vectors in Gaussian Vector Autoregressive Models, „Econometrica”, vol. 59, http://dx.doi.org/ $10.2307 / 2938278$.

Johansen S. [1992], Determination of Cointegration Rank in the Presence of a Linear Trend, „Oxford Bulletin of Economics and Statistics”, vol. 54, http://dx.doi.org/ 10.1111/j.1468-0084.1992.tb00008.x.

Kośko M., Osińska M., Stempińska J. [2007], Ekonometria współczesna, „Dom Organizatora", Toruń.

Koyama Y. [2011], Flying Geese Pattern and the Western Balkans, Conference Proceedings, The Ninth International Conference: „Challenges of Europe: Growth and Competitiveness - Reversing the Trends", Faculty of Economics, University of Split. 
Krugman P.R., Obstfeld M. [2007], Ekonomia międzynarodowa. Teoria i polityka, t. 1, Wydawnictwo Naukowe PWN, Warszawa.

Kusideł E. [2000], Modele wektorowo-autoregresyjne VAR. Metodologia i zastosowania [w:] Dane panelowe i modelowanie wielowymiarowe w badaniach ekonomicznych, red. B. Suchecki, t. 3, Absolwent, Łódź.

Lütkepohl H. [2007], New Introduction to Multiple Time Series Analysis, corr. 2nd print, Springer, Berlin.

Misala J. [2011], Międzynarodowa konkurencyjność gospodarki narodowej, PWE, Warszawa.

Misala J., Pluciński E.M. [2000], Handel wewnątrzgałęziowy między Polska a Unia Europejska. Teoria i praktyka, SGH, Warszawa.

Osińska M. [2006], Ekonometria finansowa, PWE, Warszawa.

Ozawa T. [1992], Foreign Direct Investment and Economic Development, „Transnational Corporation", vol. 1, nr 1.

Papież M., Śmiech S. [2012], Wykorzystanie modelu SVECM do badania zależności pomiędzy cenami surowców a cenami stali na rynku europejskim w latach 2003-2011, „Przegląd Statystyczny”, Komitet Statystyki i Ekonometrii PAN, t. 59, z. 4.

Salamaga M. [2013], Modelowanie wpływu bezpośrednich inwestycji zagranicznych na handel zagraniczny $w$ świetle wybranych teorii ekonomii na przykładzie krajów Europy Środkowo-Wschodniej, Zeszyty Naukowe, Seria Specjalna: Monografie nr 223, Wydawnictwo Uniwersytetu Ekonomicznego w Krakowie, Kraków.

Tarasiński L. [2009], Bezpośrednie inwestycje zagraniczne a bilans handlowy i struktura przewag komparatywnych [w:] Wptyw bezpośrednich inwestycji zagranicznych na konkurencyjność polskiej gospodarki, red. E. Frejtag-Mika, PWE, Warszawa.

\section{An Application of the VECM Model to Study the Long-term Relationship between Export and Comparative Advantages Pattern in Poland \\ (Abstract)}

The paper presents the dynamic relationship and pattern between export and comparative advantages in Poland. The basic tool used for this study is vector autoregression models. For a more detailed identification of the dynamic interactions between the variables, the results of the impulse response functions and forecast error variance decomposition are analysed. The results provide a benchmark for determining the phase of economic development according to the Ozawa's theory of dynamic comparative advantages. The important part of this theory applies to the long-term relationship between export and revealed comparative advantage indexes of goods that have a different share of the production factors. Data from the Central Statistical Office covering the period from the first quarter of 2002 to the fourth quarter of 2012 were used for the calculations.

Keywords: export, revealed comparative advantage index, VAR model, VECM model. 